\title{
CR Research Square \\ GIS-Based Weights-of-Evidence Model for Landslide Susceptibility Mapping and Assessment in the Hillslopes of Bujumbura, Burundi
}

Désiré Kubwimana ( $\nabla$ desire.kubwimana@ub.edu.bi )

Mohammed V University of Rabat: Universite Mohammed V de Rabat https://orcid.org/0000-00020315-4123

\section{Lahsen Ait Brahim}

Mohammed V University of Rabat: Universite Mohammed V de Rabat

Abdellah Abdelouafi

Mohammed V University of Rabat: Universite Mohammed V de Rabat

\section{Research}

Keywords: Landslides, controlling factor, statistical approach, susceptibility, Burundi

Posted Date: February 1st, 2021

DOl: https://doi.org/10.21203/rs.3.rs-155143/v1

License: (c) (i) This work is licensed under a Creative Commons Attribution 4.0 International License. Read Full License 


\section{Abstract}

The aim of this research is the modelling of landslide susceptibility in the hillslopes of Bujumbura using the Weights-of-Evidence model, a probabilistic data modelling approach relevant for predicting future landslides at a regional scale. Initially, characteristics and spatial mapping of different landslides type were identified (fall, flow, slide, complex) by thorough interpretation of high-resolution remote sensing data (mountainous areas with difficult access) and intensive fieldwork. Subsequently, the main landslides controlling factors were selected (lithology, fault density, land use, drainage density, slope aspect, curvature, slope angle, and elevation) using in-depth field knowledge and relevant literature. A landslide inventory map with a total of 569 landslide sites was constructed using the data from various sources. Out of those 569 landslide sites, 285 (50.1\%) of the data taken before the 2000 s was used for training and the remaining 284 (49.9\%) sites (post-2000 events) were used for the accuracy assessment purpose. Thereafter, a prediction map of future landslides was generated with an accuracy of $73.7 \%$. The main geo-environmental landslides factors retained are the high density of drainage networks, the lithology often made with weathered gneiss, the high fault density, the steep topography and the convex slope curvature. The landslide susceptibility map validated was reclassified into very high, high, moderate, low and very low zones. The established susceptibility map will allow with the interaction of the real terrain to locate roads, dwellings, urban extension areas, dams located in high landslides risk zones. These infrastructures will require intervention to address their vulnerability with new facilities, slope stabilization, creation of bypass roads, etc. The susceptibility map produced will be a powerful decisionmaking tool for drawing up appropriate development plans. Such an approach will make it possible to mitigate the socio-economic impacts due to slope instabilities.

\section{Introduction}

Tropical Africa, especially the East African Rift Valley region is more affected by landslides (Broeckx et al. 2018). Heavy rainfalls with rapid weathering partly explain the high distribution of landslides (Monsieurs et al. 2017). Moreover, steep slopes associated with the uplifting and tectonic fault system would be the main cause of historical deep-seated landslides (Dille et al. 2019). The mountains of North TanganyikaKivu Rift region where sit the hillslopes of Bujumbura are characterized by a scarcity of landslides data (Jacobs et al. 2018, Dewitte et al. 2020). One of the reasons for the landslides data-scarcity is the low capacity of the local policy (Maes et al. 2017). In addition, spatial landslides data collection is constrained with persistent clouds, rapid vegetation growth which hinders the obvious interpretation of satellite images (Wilson and Jetz 2016; Nobile et al. 2018; Dille et al. 2019; Robinson et al. 2019), and the difficult conditions of field accessibility (Jacobs et al. 2017).

Furthermore, the hillslopes of Bujumbura are affected by landslides (Depicker et al. 2020b; Dewitte et al. 2020). However, a reliable landslide inventory and accurate susceptibility still lacking. Only 89 landslides have already been inventoried (Nibigira et al. 2015; Shirambere et al. 2018). Susceptibility analysis at regional scale has shown that the region is predisposed to various landslides processes (Jacobs et al. 2018; Kubwimana et al. 2018; Monsieurs et al. 2018; Shirambere et al. 2018; Depicker et al. 2020b; 
Nsengiyumva et al. 2019). Therefore landslides damaged from simple destruction to the loss of several human lives (e.g., Reliefweb 2014). Nevertheless, accurate landslide susceptibility analysis is too limited at the North Tanganyika- Kivu Rift (Monsieurs et al. 2018; Depicker et al. 2020b). At Bujumbura hillislopes scale, Nibigira et al. (2015) and Kubwimana et al. (2018) attempted to assess the susceptibility using a multi-criteria approach where slope, lithology and fault density were found to be the main geoenvironmental drivers of landslides. Looking at landslides and their characteristics used for model validation, we argue that these two studies are too weak for landslide susceptibility assessment of the hillslopes of Bujumbura. This new approach will be accurate landslide susceptibility assessment compared to what is already known.

We used a suitable bivariate statistical approach never used in the region (WofE) to carry out this research another to assess the susceptibility of spatial occurrence of future landslides. The study focuses on assessing the rugged hillslopes of Bujumbura, where many landslides impacts are concentrated in Burundi (Moeyersons and Trefois 2012; Reliefweb 2014). Our approach assumes that the current landslide susceptibility available is biased due to the underestimation of landslides used during its development (e.g., Nibigira et al. 2015; Kubwimana et al. 2018). The new susceptibility map will be, therefore, an effective tool for the civil protection authorities in charge of the early warning system another to reduce the landslides damages. Moreover, the landslide susceptibility map will be used for planners to better grasp high-risk areas where many efforts will be highlighted during land-use management. Therefore, the landslide susceptibility map will used to draw up any development project and, on the other hand, to anticipate the occurrence of landslides in inhabited areas and in the vicinity of important infrastructures (roads, dams etc.).

\section{Study Area}

The hillslopes of Bujumbura selected for this study are located in the west of Burundi within $491 \mathrm{~km}^{2}$ (Fig. 1). In this area, the population is high with an average of over 500 inhabitants per square kilometre ("Kirasa Energy", n.d.). It is a mountainous area particularly most prone to landsliding compared to other regions of Burundi. The elevation varies between $758 \mathrm{~m}$ to $2467 \mathrm{~m}$ above sea level (a.s.I) and the slope angle varie from 0 to $76^{\circ}$. In addition, the study area is a humid tropical climate with a wet season (September - May) alternating with the dry season (June - August). The average annual precipitation calculated over a section of the study area (the southern) where the hydropower dam is being built on the Kirasa river is $1400 \mathrm{~mm}$ with an average temperature of $19^{\circ} \mathrm{C}$ ("Kirasa Energy", n.d.). The long rainy season during nine months per year explains a high density of the hydrographic network with active rivers which crossing the steep topography and then incising vertically and generating river landslides and bank erosion (Moeyersons and Trefois 2012). For geomorphological setting, low slope angles are founded in the West followed by very steep topography associated to recent tectonic uplift with North-Southern oriented active faults system (Smets et al. 2016; Delvaux et al. 2017) and the Eastern with moderate slopes. The lithology is dominated by complex rocks of Precambrian age. The Precambrian rock are metamorphic rocks (gneiss, quartzite and metaquatzite) with magmatic intrusions (granite, pegmatite) dominant in most of the study area (Fig. 2). Recent rift sediments of Pleistocene age are located in the 
lower western part (Fig. 2). Land use is classified in three units (1) the built-up area with a high extension due to the high demographic pressure over the last few decades, following the rural exodus of the massive population to settle in the urban and peri-urban area of Bujumbura, (2) the more abundant forest in the East which is gradually disappearing towards the west to cope with human activities and (3) agricultural land with low to moderate vegetation and scattered trees (Mboga et al. 2020).

\section{Methods}

\subsection{Landslide inventory}

The characteristics, spatial mapping and inventory of different landslides type in the hillslopes of Bujumbura were first identified from Moeyersons and Trefois (2012), Reliefweb (2014), Jacobs et al. (2018); Kubwimana et al. (2018), Monsieurs et al. (2018), Shirambere et al. (2018), Depicker et al. (2020b) and Nsengiyumva et al. (2019). They were then completed by our analysis of satellite images of highresolution aerial ortho-photographs $(0.5 \mathrm{~m})$, obtained within the framework of the CBUE (2013) and, finally our surveys in very intensive fieldwork from 2013 to present. We provided a data catalogue with 569 landslides (Fig. 3) classified according to Hungr et al. (2014) in rotational slide (e.g., Fig. 4a), complex (e.g., Fig. 4b), translational slide (e.g., Fig. 4c), earthflows (e.g., Fig. 4d), slide/avalanche (e.g., Fig. 4e), etc. Frome the 569 landslides, hereafter we have five examples of landslides characteristics as inventoried for the whole database.

1- 2018: in the region of Winterekwa (Bujumbura), a rotational slide $\left(29,409^{\circ} ;-3,346^{\circ}\right)$ is developed on South West - North East facing and exposed towards the North. The elevation varies between $940 \mathrm{~m}$ a.s.l and $970 \mathrm{~m}$ a.s.I and the slope angle is ranged between $10-15^{\circ}$. Its surface area is $5914 \mathrm{~m}^{2}$. This region is characterised by rift sediments of Pleistocene age and is affected by a normal fault (N20). The area is urbanised with disordered building without a reliable drainage system. This landslide led to the destruction of more than 35 houses.

2- 2014: in the region of Gikoma, a landslide of translational type $\left(29,409^{\circ} ;-3,346^{\circ}\right)$ occurred on North West - South East slope exposed towards the West. The elevation varies between $1050 \mathrm{~m}$ a.s.I and $1100 \mathrm{~m}$ a.s.l and the slope is between $25-30^{\circ}$. Its surface area is $9868 \mathrm{~m}^{2}$. This region is characterised by rift sediments of Pleistocene age (conglomeratic sandstone). Vegetation is mainly formed by food crops. The landslide depletion zone is located near the National Road $1(1 \mathrm{~m})$ which connects the city of Bujumbura to the city of Kigali. A potential reactivation could cut the NR 1, the main road to Rwanda.

3- In Rohe (Kanyosha), a complex old slide - earthflow (Fig. 4b; $29,388^{\circ} ;-3,433^{\circ}$ ) has developed on the slope of a valley oriented North West - South East and exposed towards the North West. The altitude varies between $950 \mathrm{~m}$ a.s.I and $1200 \mathrm{~m}$ a.s.l, the slope is between $25-30^{\circ}$. Its surface area is $494693 \mathrm{~m}^{2}$. This region is characterised by the presence of strongly altered Precambrian gneisses and affected by a normal fault N170. Vegetation consists mainly of food crops and oil palm trees. This landslide destroyed 
several houses. In the historical aerial photos of 1980s, dozens of houses appear in the landslide body but they have now disappeared.

4- In Muyira, a flowslide $\left(29,428^{\circ} ;-3.408^{\circ}\right)$ has developed on the slope of a valley oriented North - South and exposed towards the West. The altitude varies between $1350 \mathrm{~m}$ a.s.I and $1500 \mathrm{~m}$ a.s.l, the slope is between $25-30^{\circ}$. Its surface area is $42050 \mathrm{~m}^{2}$. This region is characterised by the presence of a high altered granite. Vegetation is not very dense and consists mainly of food crops. This landslide totally destroyed the Muguye primary school in 2013.

5- In the region of Kabumba (Buhonga), an old earthflow (Fig. 4d, 29,400 $;-3,430^{\circ}$ ) has developed on the slope of a valley oriented in West - East and exposed towards the South. The altitude varies between $1050 \mathrm{~m}$ a.s.I and $1350 \mathrm{~m}$.a.s.l, the slope is between $20-25^{\circ}$. Its surface area is $416359 \mathrm{~m}^{2}$. This region is characterised by the presence of highly altered Precambrian gneiss. The vegetation consists mainly of banana and palm oil trees. The landslide has damaged completely the National Road 7 (main access road to the southern provinces).

\subsection{Parameterization of independent variables}

The source of the topographic variables, here the Digital Elevation Model (DEM) is essential input data for landslide susceptibility mapping (Fressard et al., 2014). In order to obtain an adequate and accurate topographic data, we used a DEM from available orthomosaics covering Burundi (CBUE 2013) chosen for its very good spatial resolution $(10 \mathrm{~m})$ more suitable to the accuracy required within this study. The landslide controlling factors are selected based on the literature review and a thorough knowledge of the terrain (Van Westen et al. 1999; Van Westen 2007). With the 10m-DEM, we generated five landslides controlling factors including slope aspect, curvature, slope angle, drainage density and elevation (Figs. 5a $-\mathrm{f}$ ). The five topographic factors and fault density are continuous variables reclassified according to Natural Breaks (Jenks) while the land use and land cover and lithology are categorical variables reclassified according to their normal units (Figs. 5g,h).

\subsubsection{Slope aspect}

Solar radiation depends on slope exposure, which controls soil moisture as well as precipitation, as it has a pronounced directional component depending on the orientation of the slope (Mastere et al. 2010, Ait Brahim et al. 2018). A slope more exposed to the sunlight will receive a lot of precipitation and will be highly susceptible to landslides occurrence. The slope aspect map has been classified with ArcGIS 10.2.2 into eight classes (North, North-East, East, South-East, South, South-West, West, and North-West) (Fig. 5a)

\subsubsection{Curvature}

The concavity of the slopes is an important factor for the analysis of landslides susceptibility. In fact, a more convex slope will be exposed to landslides than a concave slope. The concavity was determined using ArcGIS tool and reclassified into three classes (Concave, Plane, and Convex) according to Natural Breaks Jenks (Fig. 5b). 


\subsubsection{Slope angle}

The slope angle controls landslides in the study area. Kubwimana et al. (2018) showed that the slope angle controlled landforms in a central zone of the study area, the watershed of Kanyosha. In this study, we computed slope angle $10 \mathrm{~m}$ DEM-based under ArcGIS 3D analysis tools. The result obtained was reclassified into nine classes $\left(0-5^{\circ}, 5-10^{\circ}, 10-15^{\circ}, 15-20^{\circ}, 20-25^{\circ}, 25-30^{\circ}, 30-35^{\circ}, 35-40^{\circ},>40^{\circ}\right)$ according to Natural Breaks Jenks (Fig. 5c).

\subsubsection{Drainage line density}

The drainage line density plays a key role in the occurrence of landslides. Indeed, during the percolation through fracture zones, water accelerates landslides. In addition, during floods, water erodes the riverbanks as observed by Moeyersons and Trefois (2012). The hydrographic network was automatically achieved using Archydro tool in ArcGIS 10.20.2. The realized density map was reclassified into five classes from the lowest to the highest density of the hydrographic networks (Fig. 5d)

\subsubsection{Elevation}

Elevation is certainly one of the variables most often used when we deal with landslides, particularly because of its relationship with rainfall in areas with strong differences in altitude (Gallart and ClotetPerarnau, 1988). The elevation was obtained directly using the DEM $1 \mathrm{~m}$ without any particular transformation. The elevation is measured in metres above mean sea level. They are measured and vary from 759 to 2467 m.a.s.I for our study area. The altitudes have also been divided into classes. The lower altitudes receiving less rainfall are less predisposed to landslides and the higher altitudes are very exposed to landslides (Fig. 5f).

\subsubsection{Fault density}

Schistosity, fracturing, stratification or fault planes are areas of weakness where landslides occur (Kubwimana et al. 2018). The fault density was collected by digitalization on the geological map, a sheet of Bujumbura at 1/50000 (Laghmouch et al. 2018). We collected all active faults available in the area and reclassified into four classes (Fig. 5f). Delvaux et al. (2017) showed that active faults are associated with the African rifting. In the region of Bujumbura, these faults are oriented to North-South direction.

\subsubsection{Land use}

The study area is largely dominated by low vegetation/or simply by bare soil/or agricultural land. The highly urbanized west zone corresponds to the building and road networks (Fig. 2). The eastern is dominated by high forests whose population remove slowly for agricultural land. The land use was performed by digitalisation of $0.5 \mathrm{~m}$ resolution orthomosaics (CBUE 2013) and very high-resolution Google Earth images (USGS 2006). The land use map was reclassified into five classes (urban, agricultural land or bare soil Forest, quartzitic soil and quarrying) (Fig. $5 \mathrm{~g}$ ).

\subsubsection{Lithology}


The geology is among the main controlling factor of landslides in the study area and in the region (Jacobs et al. 2017; Kubwimana et al. 2018). The spatial landslides distribution showed that most of the landslides occurred in outcrops within gneissic or granite units (Kubwimana et al. 2018). To extract the lithological units, we digitalized the geological map of Burundi, Bujumbura sheet at 1/50000 (Laghmouch et al. 2018). The lithological map produced showed a lithological variation categorised into five classes (Fig. 5h).

\subsection{Weights-of-Evidence approach (WofE)}

To carry out this study, we performed a bivariate statistical approach using the WofE method. It is a probabilistic approach for Spatial Data Modelling (SDM) which involves determining the probability of a region undergoing the future landslides (Sawatzky et al. 2009). The WofE model is based on the principle of uniformity which states that future landslides will occur under similar conditions of the past (Abella et al. 2007; Fressard et al. 2013). This indirect mapping approach characterizes the extent of occurrence of landslides based on landslide conditioning factors (Soeters and Westen 1996). In order to achieve this model, we integrated landslides conditioning factors into GIS and then converted to raster integer (Westen et al. 2003) before being subjected to the statistical treatments (Fig. 4). Then, we calculated the landslides posterior probability using independent predictive variables (predictor variable, Pv). In fact, the likelihood ratio approaches (Lee and Talib 2005) are based on observed relationships between landslide distribution (dependent variable, Dv) and each landslide related factor to reveal the correlation between landslide locations and the factors involved the predictors. The association between Dv and Pv will thus make it possible to calculate a positive weight $\mathrm{W}^{+}(1)$ and a negative weight $\mathrm{W}^{-}$(2) for each predictive variable, corresponding respectively to a greater or a lower probability of occurrence of Dv (Elmoulat et al. 2018). The formula below will allow us to calculate the specific weight each criteria and will be based on the ratio calculated from the empirical relationship with landslides and their causative factors.

$$
\begin{aligned}
& \mathrm{W}^{+}=\ln \frac{\left.\mathrm{P}_{\{} \mathrm{Pv} / \mathrm{D} \mathrm{v}\right)}{\left.\mathrm{P}_{\{} \mathrm{PV} / \overline{\mathrm{Dv}}\right\}} \\
& W^{-}=\ln \frac{P_{\{}\left(\overline{P_{v}} / D v\right)}{\left.\mathrm{P}_{\{} \overline{\mathrm{P}_{v}} / \overline{\mathrm{Dv}}\right\}} \\
& \mathrm{C}=\mathrm{W}^{+}-\mathrm{W}^{-}
\end{aligned}
$$

Where $\mathrm{C}$, is a contrast and $\mathrm{P}$, the probability.

To achieve this study, we performed seven steps listed hereafter and summarised in Fig. 4: (1) identification and cartography of predictive factors and landslides, (2) reclassification and standardisation of evidential themes, (3) generation of evidence weights tables for themes according to their relationships with landslides, (4) weighted evidential maps were combined to produce a posterior probability map, (4) assessment of conditional independence, (5) evaluation of the resulting map prediction accuracy and (7) landslide susceptibility map generation and validation.

\subsection{Susceptibility modelling and performance analysis}


The landslides inventory is the main component of any landslide susceptibility assessment (Van Westen et al. 2006). The landslides inventory was collected combining intensive field investigation, analysis of high-resolution satellite images such as professional Google Earth imagery and $0.5 \mathrm{~m}$ spatial resolution of orthomosaics (CBUE 2013). For the calibration of the WofE model, we must select a part of the landslides to be used in the training and another part for testing and validation. According to Pradhan and Lee (2010), there is no universal rule for selecting the ratio of testing and training dataset. In our case, the WofE model was calibrated with $50.1 \%$ (285 training landslides) and validated with the remaining 49.9\% (284 testing landslides). The calibration landslides were not selected randomly but based on the period of spatial occurrence i.e. triggered before the 2000s and therefore independent to testing landslides activated afterwards. The differentiation of landslides timing was done using Google Earth imageries available from the 2000s to present and the interviews of local people in field surveys. Testing landslides was at least occurred during the last two decades. The model performance was calculated automatically using the SDM (Sawatzky et al. 2009). To increase the performance of the model, we recombined landslides controlling factors removing one by one and taking a high accuracy value as used in lovine et al. (2014). Low accuracy indicated that the removed factor is more important and vice versa. For validation of datasets, we calculated automatically the Conditional Independence Ratio (CIR) using the SDM in order to validate if landslides controlling factors are independent each other (Sawatzky et al. 2009). CIR $>1$ indicated that there is independence between variables in the model (Bonham-Carter et al. 1989). Finally, we calculated the Area Under Curves (AUC) using Success Rate Curve (SRC) and Predictive Rate Curve (PRC) automatically using the SDM (Sawatzky et al. 2009). According to Sawatzky et al. (2009), the accuracy $\geq 50 \%$ is acceptable for landslide susceptibility modelling. The data collection and treatments that enabled us to produce the susceptibility map are shown in Fig. 6.

\section{Results And Discussion}

The Weights-of-Evidence (WofE-0 to WofE-8) experiments are shown (Table 1). In WofE-0 with all variables, the landslide prediction model accuracy is $72.2 \%$. It is a satisfactory value because it is more than 50\% (Sawatzky et al. 2010). A WofE model performance improvement was made recombining seven independent variables (Table 1). Small accuracy values i.e less than the WofE-0 have been found successively when removing drainage density (69.1\%), land use (69.9\%), geology $(70.4 \%)$, fault density (70.8\%), slope angle $(71.1 \%)$ and curvature $(71.8 \%)$. These are the major landsides controlling factors in the study area. These landslides controlling factors are broadly similar to those found in previous studies, except that the order often change (Kubwimana et al., 2018; Moeyersons and Trefois 2012; Jacobs et al. 2018). For example, Kubwimana et al. (2018) highlight the lithology, the fault system and the drainage density as main landslides controlling factors. The fourth position of the slope angle seems anomalous if we consider earlier studies where it is among the first landslides controlling factors (Kubwimana et al. 2018; Jacobs et al. 2017). The relatively low weighting of the slope angle factor would be due to the fact that shallow landslides were not considered in this study as training landslides (Fig. 3). We dealt with landslides before the 2000s for training points, or old landslides are deep-seated because, in the 
landscape, shallow landslides disappeared in few years due to rapid erosion and weathering processes (Dewitte et al. 2020), whereas they are more gravity-induced and sensitive to climatic and geoenvironmental constraints (Sidle and Bogaard 2016). This low correlation slope angle to deep-seated landslides comes to support that in hillslopes of Bujumbura, old deep-seated landslides are not only gravity-controlled but rather to other facets such as the geodynamics process (Depicker et al. 2020b). Here it is shown with the landslides distribution in the high fault density (Table 2). The land use and land cover not considered in the previous multi-criteria analysis (Kubwimana et al. 2018) have shown a high control of landslides, as well as curvature, except that their influence is small. In addition, the high values of accuracy were found when removing the slope aspect (73.7\%) and elevation (72.2\%). The lack of slope aspect control in landslide occurrence was previously predicted (Jacobs et al. 2017; Kubwimana et al. 2018). The reason is that the region belongs to the tropical climate where slopes are exposed to the sunlight in the same way and therefore receive the same precipitation. There is no obvious variability in landslide occurrence associated with slope aspect. For elevation, the lack of landslide control would be related to the small scale of the study which implies insignificant climatic variations.

For the slope aspect, south-west facing slopes show a positive correlation with landslides. This would be related to the wind direction of the region are oriented towards the southeast, thus directing rainfall to the southeast to strike the southwest-sided slope. The curvature has shown that landslides occur on convex slopes. The reason is that landslides occurrence depends on the shape of the slope here most significant for convex slopes. Moreover, the convex slopes are sunnier and therefore susceptible to landsliding. For the slope, the most susceptible angle to landslides is between $20-25^{\circ}$. Jacobs et al (2017) highlight the angle of friction of the gneisses $\left(23-29^{\circ}\right)$ as the cause. The positive correlation in slope between $35-40^{\circ}$ would be related to gravity control (Sidle and Bogaard 2016). The faults show a good correlation for the highest density, which is consistent with the literature (e.g., Kubwimana et al. 2018), and then support a tectonic control of landslides occurred in the region (Delvaux et al. 2017). The lithology is positive in the gneiss units consistent with Jacobs et al. (2017) at a regional scale and Kubwimana et al. (2018) locally. The distribution of landslides in gneisses may be due to their high alterability into thick regoliths. Land use and land cover is positive in urban, bare or agricultural soils and in quarries (Table 2). The positive correlation of landslides in urban, bare or agricultural soil would justify the rule of anthropogenic action in landslide occurrence. The high demographic increase and the associated extension of the city of Bujumbura, which does not comply with planning standards would be the main cause of the landslide susceptibility linked to urbanisation. In addition, the lack of arable lands leads to deforestation, which increases the landslide susceptibility (Depicker et al. 2020a). Landslides in quarries could be explained by uncontrolled quarries that do not respect environmental conditions. The high landslides in low elevation are related to geomorphology. Lower areas are rift deposits zone with unconsolidated sediments prone to landsliding.

The CIR calculated is 1.1 which is greater than 1 i.e. the variables are therefore independent (BonhamCarter et al. 1989). The WofE-1 with a prediction rate of $73.7 \%$ is the most efficient for characterising the posterior probability of landslides in this study. The corresponding probability map was then generated by combining five variables including curvature, slope angle, drainage density, road density, fault density, 
lithology and land use/land cover. In order to simplify the resulting probability map, the probability values were reorganised into five classes using Natural Breaks (Jenks) classification method designed to determine the best arrangement of values in different classes (Figs. 7a,b).

In order to test the validity of the WofE model, we analysed the posterior probability map using the success and predictive rates curves (AUC and PRC), which are the most important means of evaluating the landslide susceptibility map. The AUC and PRC are $68.5 \%$ and $73.7 \%$ for predicting known and unknown landslides respectively (Fig. 8). These values are valid for the WofE model used to assess the landslide susceptibility (Sawatzky et al. 2009).

The landslide susceptibility map generated from the applied bi-variate statistical approach is shown in Fig. 7. The WofE model showed that the areas of very low, low, moderate, high and very high landslide susceptibility constitute $23 \%, 11 \%, 16 \%, 19 \%$ and $31 \%$ of the study area respectively. The landslide distribution showed that $19 \%$ and $50 \%$ of the landslides inventory are in high and very high landslide susceptibility areas respectively (Fig. 8). This allows us to validate the model used. This very high landslide susceptibility is supported with several damages to infrastructures in the hillslopes of Bujumbura (roads, schools, houses, hydroelectric power station, markets, sanitation, etc). This study was limited to assessment of landslide susceptibility but could be completed by a risk assessment is populated hillslopes of Burundi. Yet the landslide susceptibility maps will help management planners to mitigate the frequent landslides impacts.

\section{Conclusion}

In order to predict or reduce potential slopes instabilities damage in the hillslopes of Bujumbura, research on the landslides inventory, characterization and susceptibility assessment has been carried out as part of the PhD thesis project. The present work is a continuation of this research, which aims to assess the landslides susceptibility of the populated hillslopes of Bujumbura using the Weights-of-Evidence modelling approach. This is a statistical approach more used in predictive modelling. However, it had never been used in landslide modelling in the region or locally. This method comes to complement previous studies particularly the multi-criteria analysis already carried out in area. To perform this study, we used an inventory of 569 landslides divided into training and validation datasets (285 vs. 284) according to the period of occurrence in order to respect the conditional independence. Input, old landslides triggered before the 2000s were used for calibration and remaining landslides post 2000 events was used for validation process. The validation was done using the Area Under Curve frequency and showed that the landslide susceptibility map produced predict future landslides at $73.7 \%$. The application of the Weights-of-Evidence method is effective for assessing the landslides susceptibility in the study area. The landslides predictor variables used are independent with a CIR of 1.1. The main geoenvironmental factors for landslides are drainage networks, land cover/land use, geology, slope angle and fault density. The most areas susceptible to landslides are gneiss units, high-density fault zones, areas with slopes between $25-30^{\circ}$ and $35-40^{\circ}$, agricultural land and quarries, while the most stable areas are forests. This article will be useful for future researchers using mainly the expert method for 
weighting the landslide causative factors. It will be useful to the civil authorities in charge of the early warning system by guiding in the choice of sites for the installation of real-time monitoring devices in areas of very high landslides susceptibility. This map is also a powerful decision-making tool for drawing up development plans (urban extension, new road, etc). Such an approach will make it possible to mitigate the socio-economic impacts of slope failures in the hillslopes of Bujumbura.

\section{Declarations}

\section{Availability of data and material}

The DEM and orthomosaics images come from the Bureau de Centralisation Géomatique du Burundi. Demographic data are available at ISTEEBU. Climatological data are available at IGEBU. The geological map comes from the Ministry of Energy and Mines of Burundi. The road network data has been uploaded on Open Streets Maps. Anyway, the datasets used and/or analysed during this study are available from the corresponding author and can be sent upon reasonable request.

\section{Competing interests}

The authors declare that there is no conflict of interest regarding the publication of this article.

\section{Fundings}

This study was carried out within the framework of a doctoral thesis financed by bilateral cooperation between the Republic of Burundi and the Kingdom of Morocco via the Moroccan Agency for International Cooperation (AMCl) and the Bureau des Bourses d'Etudes et des Stages (BBES). DK has obtained fundings for field research from ARES / PFS, RESIST and GeoRisCA.

\section{Authors' contributions}

DK collected landslide data using interpretation of satellite images and aerial photos and intensive field visits. In addition, KD carried out the statistical analysis of the data, the mapping and the writing of the manuscript. LA and AA checked the validity of collected data and statistical analysis and corrected the manuscript. All authors have read and approved the manuscript.

\section{Acknowledgments}

Thanks to students of the Earth Sciences Department, University of Burundi, assisted us in the field for data collection

\section{References}

Abella EAC, Van Westen CJ (2007) Generation of a landslide risk index map for Cuba using spatial multicriteria evaluation. Landslides 4:311-325 (2007). https://doi.org/10.1007/s10346-007-0087-y 
Ait Brahim L, Jemmah, Al, Bousta M, El Hamdouni I, Abdelouafi A, El Mahsani A, Merouni FE (2018) Spatial correlation between the predictor variables and the weighting values calculated during the mapping of the environmental factors of mass movements in the Beni Idder region (northern Rif). In MATEC Web of Conferences, p. 02074. https://doi.org/10.1051/ matecconf/201814902074CMSS-2017

Bonham-Carter GF, Agterberg FP, Wright DF (1989) Weights-of-Evidence modeling: a new approach to mapping mineral potential. In: Agterberg FP, Bonham-Carter, GF (Eds.) Statistical Applications in the Earth Science: Geological Survey of Canada Paper 89:171-183

Broeckx J, Vanmaercke M, Duchateau R (2018) A data-based landslide susceptibility map of Africa. Earth-Science Rev 185:102-121. https://doi.org/10.1016/j.earscirev.2018.05.002

Carrara A, Cardinali M, Guzzetti F and Reichenbach P (1995) GIS-based techniques for mapping landslide hazard. In: Carrara AF, Guzzetti F (Eds) Geographical information systems in assessing natural hazards. Springer, Dordrecht, pp. 135-175

CBUE (2013) Développement du secteur de la géomatique au Burundi: Avec le support de l'Union Européenne, le Gouvernement du Burundi se dote d'une couverture nationale en ortho photographies aériennes de très haute résolution. http://spbcg.gov.bi/images/Coopération_Burundi_Union_Européenne.pdf. Accessed 23 Sep 2020

Delvaux D, Mulumba JL, Sebagenzi MS, Bondo FS, Kervyn F, Havenith H-B (2017) Seismic hazard assessment of the Kivu rift segment based on a new seismotectonic zonation model (western branch, East African Rift system). J African Earth Sci 134:831-855.

https://doi.org/10.1016/j.jafrearsci.2016.10.004

Depicker A, Govers G, Jacobs L, Campforts B, Uwihirwe J, Dewitte O (2020a) Interactions between deforestation, landscape rejuvenation, and shallow landslides in the North Tanganyika - Kivu Rift region, Africa. Earth Surface Dynamics Discussions.

Depicker A, Jacobs L, Delvaux D, Havenith H-B, Maki Mateso J-C, Govers G, Dewitte 0 (2020b) The added value of a regional landslide susceptibility assessment: the western branch of the East African Rift. Geomorphology 353:106886. https://doi.org/10.1016/j.geomorph.2019.106886

Dewitte O, Dille A, Depicker A, Kubwimana D, Maki-Mateso JC, Mugaruka Bibentyo T, Uwihirwe J, Monsieurs E (2020) Constraining landslide timing in a data-scarce context: from recent to very old processes in the tropical environment of the North Tanganyika-Kivu Rift region. Landslides. https://doi.org/10.1007/s10346-020-01452-0

Dille A, Kervyn F, Mugaruka Bibentyo T, Delvaux D, Bamulezi GG, llombe GM, Kalikone BC, Nakito ES, Moeyersons J, Monsieurs E, Nzolang S, Smets B, Kervyn M, Dewitte 0 (2019) Causes and triggers of deepseated hillslope instability in the tropics - Insights from a 60-year record of Ikoma landslide (DR Congo). Geomorphology 345:106835. https://doi.org/10.1016/j.geomorph.2019.106835 
Elmoulat M, Ait Brahim L (2018) Landslides susceptibility mapping using GIS and Weights-of-Evidence model in Tetouan-Ras-Mazari area (Northern Morocco). Geomatics, Natural Hazards And Risk 9:13061325. https://doi.org/10.1080/19475705.2018.1505666

Fressard M, Thiery Y, Maquaire O (2014) Which data for quantitative landslide susceptibility mapping at operational scale? Case study of the Pays d'Auge plateau hillslopes (Normandy, France). Nat Hazards Earth Syst Sci 14:569-588. https://doi.org/10.5194/nhess-14-569-2014

Gallart F, Clotet-Perarnau N (1988) Some aspects of the geomorphic processes triggered by an extreme rainfall event: The November 1982 flood in The Eastern Pyrenees. Catena Supplement 13:79-95

Hungr O, Leroueil S, Picarelli L (2014) The Varnes classification of landslide types, an update. Landslides 11:167-194. https://doi.org/10.1007/s10346-013-0436-y

lovine GGR, Greco R, Gariano SL, Stefano LG, Terranova OG (2014) Shallow-landslide susceptibility in the Costa Viola mountain ridge (southern Calabria, Italy) with considerations on the role of causal factors. Nat Hazards 73:111-136. https://doi.org/10.1007/s11069-014-1129-0

Jacobs L, Dewitte O, Poesen J, Sekajugo J, Nobile A, Rossi M, Thiery W, Kervyn M (2018) Field-based landslide susceptibility assessment in a data-scarce environment: the populated areas of the Rwenzori Mountains. Nat Hazards Earth Syst Sci 18:105-124. https://doi.org/10.5194/nhess-18-105-2018

Jacobs L, Dewitte O, Poesen J, Maes J, Mertens K, Sekajugo J, Kervyn, M (2017) Landslide characteristics and spatial distribution in the Rwenzori Mountains, Uganda. J African Earth Sci 134:917-930.

https://doi.org/10.1016/j.jafrearsci.2016.05.013

Joshua West A (2018) Global toll from landslides is heaviest in developing countries. https://theconversation.com/global-toll-from-landslides-is-heaviest-in-developing-countries-90086. Accessed 21 Sep 2020

Kervyn M, Jacobs L, Maes J, Bih Che V, de Hontheim A, Dewitte O, Vranken, L (2015) Landslide resilience in equatorial Africa: Moving beyond problem identification!. Belgeo. Revue belge de géographie 1:0-22. https://doi.org/10.4000/belgeo.15944

Kirasa Energy (n.d.) Etude de l'évaluation de la vulnérabilité de l'aménagement hydroélectrique de deux centrales en cascade sur la rivière Kirasa à la variabilité et aux changements climatiques de la région. Bujumbura, Burundi

Kubwimana D, Ait Brahim L, Bousta M, Dewitte O, Abdelouafi A, Bahaj T, 2018. Landslides susceptibility assessment using AHP method in Kanyosha watershed (Bujumbura-Burundi): urbanisation and management impacts, in: MATEC Web of Conferences, p. 02071.

https://doi.org/10.1051/matecconf/201814902071 
Laghmouch M, Nimpagaritse G, Mudende L (2018) Numérisation de la carte géologique du Burundi au 50ème, Bukeye Feuille 16, Bujumbura-Mairie Feuille 22, Bujumbura Rural Feuille 23, Gakara Feuille 28, Mwaro Feuille 29. R. Museum Cent. Africa (RMCA), Dir Générale la Rech. Géologique du cadastre Min. Bujumbura, Burundi

Lee S, Talib JA (2005) Probabilistic landslide susceptibility and factor effect analysis. Environ Geol 47:982-990. https://doi.org/10.1007/s00254-005-1228-z

Maes J, Kervyn M, de Hontheim A, Dewitte O, Jacobs L, Mertens K, Vanmaercke M, Vranken L, Poesen J (2017) Landslide risk reduction measures: A review of practices and challenges for the tropics. Prog Phys Geogr 41:191-221. https://doi.org/10.1177/0309133316689344

Mastere M, Ait Brahim L, Van Vliet-Lanoë B, Elfahchouch N, Guelzime E, Jirari H, Abdelouafi A (2010). Utilization of digital photogrammetry in spatiotemporal knowledge of landslides. Geo-Canada - Working with the Earth, Alberta, Canada

Mboga N, Grippa T, Georganos S, Vanhuysse S, Smets B, Dewitte O, Wolff E, Lennert M (2020) Fully convolutional networks for land cover classification from historical panchromatic aerial photographs. ISPRS J Photogramm Remote Sens 167:385-395. https://doi.org/10.1016/j.isprsjprs.2020.07.005

Michellier C, Pigeon P, Kervyn F, Wolff E (2016) Contextualizing vulnerability assessment: a support to geo-risk management in central Africa. Nat Hazards 82:27-42. https://doi.org/10.1007/s11069-0162295-z

Moeyersons J, Trefrois P (2012) La protection du site CURGO - Kabezi - Bujumbura contre les risques hydrologiques dans le bassin de la rivière Nyabage, étude de formulation d'une opération de conservation. Bujumbura, Burundi.

Monsieurs E, Jacobs L, Michellier C, Joseph BT (2018) Landslide inventory for hazard assessment in a data-poor context: a regional-scale approach in a tropical African environment 15:2195-2209. https://doi.org/10.1007/s10346-018-1008-y

Monsieurs E, Kirschbaum D, Thiery W, van Lipzig N, Kervyn M, Demoulin A, Jacobs L, Kervyn F, Dewitte O, 2017. Constraints on Landslide-Climate Research Imposed by the Reality of Fieldwork in Central Africa, in: De Graff, J. V., Shakoor, A. (Eds.), 3rd North American Symposium on Landslides: Landslides: Putting Experience, Knowledge, and Emerging Technologies into Practice. Association of Environmental \& Engineering Geologists (AEG), ISBN 978-0-9897253-7-8, pp. 158-168

Nibigira L, Draidia S, Havenith H (2015) GIS-Based Landslide Susceptibility Mapping in the Great Lakes Region of Africa, Case Study of Bujumbura Burundi. In: Engineering Geology for Society and Territory Volume 2. Springer International Publishing, pp. 1-6 
Nobile A, Dille A, Monsieurs E, Basimike J, Mugaruka Bibentyo T, D’Oreye N, Kervyn F, Dewitte O (2018) Multi-temporal dinsar to characterise landslide ground deformations in a tropical urban environment: Focus on Bukavu (DR Congo). Remote Sens 10:1-18. https://doi.org/10.3390/rs10040626

Nsengiyumva JB, Luo G, Amanambu AC, Mind'je R, Habiyaremye G, Karamage F, Uchenna Ochege F, Mupenzi C (2019) Comparing probabilistic and statistical methods in landslide susceptibility modeling in Rwanda/Centre-Eastern Africa. Sci Total Environ 659:1457-1472.

https://doi.org/10.1016/j.scitotenv.2018.12.248

Pradhan B, Lee S (2010) Landslide susceptibility assessment and factor effect analysis: back propagation artificial neural networks and their comparison with frequency ratio and bivariate logistic regression modelling. Environmental Modelling \& Software 25:747-759.

https://doi.org/10.1016/j.envsoft.2009.10.016

Reliefweb (2014) Burundi: Floods and Landslides - Feb 2014. https://reliefweb.int/disaster/fl-2014000019-bdi. Accessed 28 Jan 2020

Robinson TR, Rosser N, Walters RJ (2019) The Spatial and Temporal Influence of Cloud Cover on Satellite-Based Emergency Mapping of Earthquake Disasters. Sci Rep 9:12455.

https://doi.org/10.1038/s41598-019-49008-0

Sawatzky DL., Raines GL, Bonham-Carter GF, Looney CG (2009) Spatial Data Modeller (SDM): ArcMAP 9.3 geoprocessing tools for spatial data modelling using weights of evidence, logistic regression, fuzzy logic and neural networks. http://arcscripts.esri.com/details.asp?dbid=15341

Shirambere G, Nyadawa M, Masekanya J, Nyomboi T (2018) Comparative assessment of landslide susceptibility by logistic regression and first order second moment method: Case study of Bujumbura Peri-Urban Area, Burundi. J Eng Res Appl 8:28-37. https://doi.org/10.9790/9622-0808022837

Sidle RC, Bogaard TA (2016) Dynamic earth system and ecological controls of rainfall-initiated landslides. Earth-Science Rev 159:275-291. https://doi.org/10.1016/j.earscirev.2016.05.013

Smets B, Delvaux D, Ross KA, Poppe S, Kervyn M, d'Oreye N, Kervyn F (2016) The role of inherited crustal structures and magmatism in the development of rift segments: Insights from the Kivu basin, western branch of the East African Rift. Tectonophysics 683:62-76. https://doi.org/10.1016/j.tecto.2016.06.022

Soeters R, van Westen CJ (1996). Slope instability recognition, analysis and zonation. Landslides: investigation and mitigation 247:129-177

Thiery Y, Malet JP, Sterlacchini S, Puissant A, Maquaire O (2007) Landslide susceptibility assessment by bivariate methods at large scales: Application to a complex mountainous environment. Geomorphology 92:38-59. https://doi.org/10.1016/j.geomorph.2007.02.020 
Van Westen CJ, Seijmonsbergen AC, Mantovani F (1999) Comparing Landslide Hazard Maps. Natural Hazards 20:137-158. https://doi.org/10.1023/A:1008036810401

Van Westen CJ, Rengers N, Soeters R (2003) Use of Geomorphological Information in Indirect Landslide Susceptibility Assessment. Natural Hazards 30:399-419.

https://doi.org/10.1023/B:NHAZ.0000007097.42735.9e

Van Westen CJ, Van Asch TW, Soeters R (2006) Landslide hazard and risk zonation - Why is it still so difficult?. Bull Eng Geol Environ 65:167-184. https://doi.org/10.1007/s10064-005-0023-0

Van Westen, C (2007) Introduction to landslides Part 1: Types and causes. International Institute for Aerospace Survey and Earth Sciences (ITC), Enschede, Netherlands

Wilson AM, Jetz W (2016) Remotely Sensed High-Resolution Global Cloud Dynamics for Predicting Ecosystem and Biodiversity Distributions. PLoS Biol 14:e1002415.

https://doi.org/10.1371/journal.pbio.1002415

\section{Tables}

Due to technical limitations, table 1 and 2 is only available as a download in the Supplemental Files section.

\section{Figures}




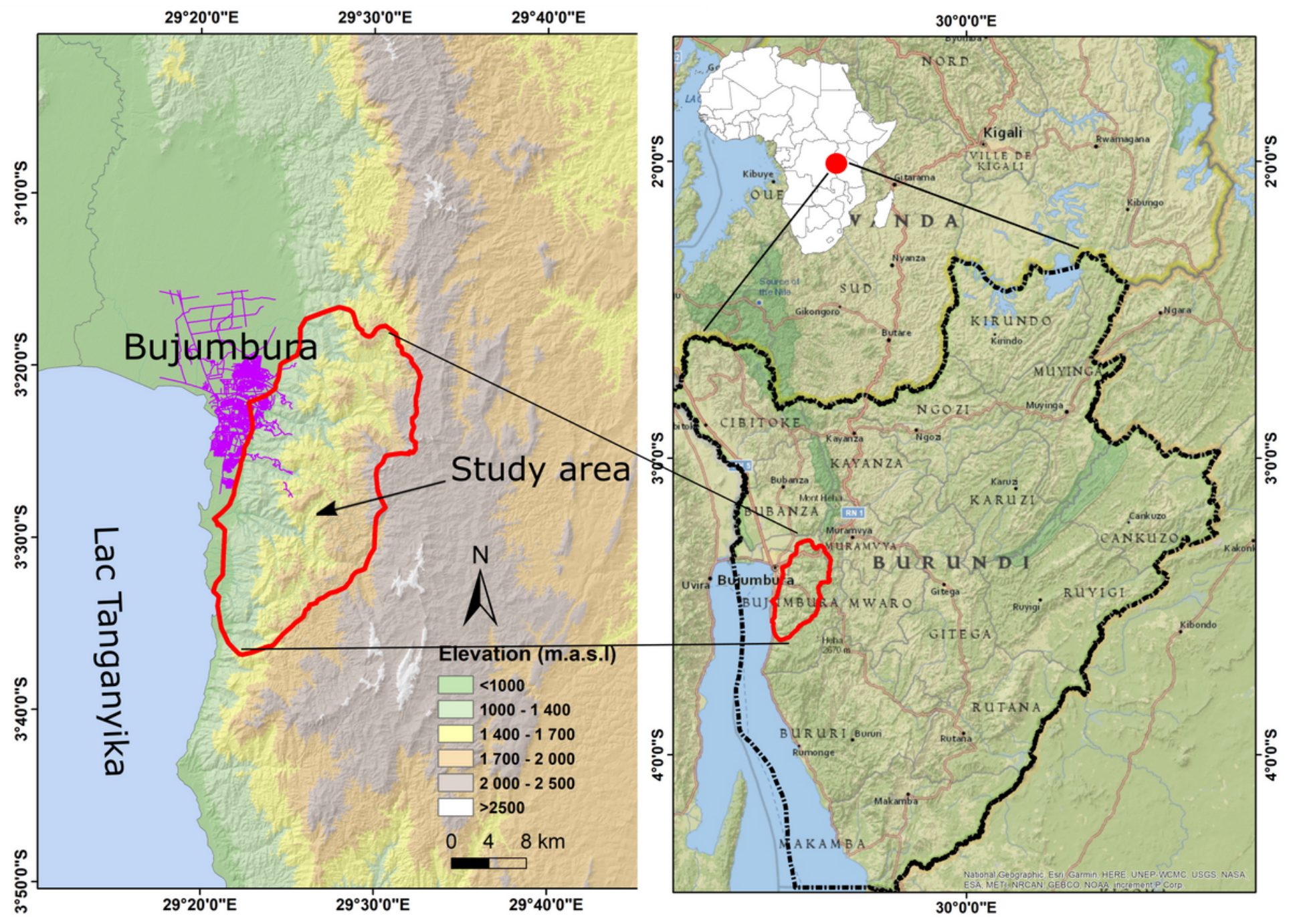

Figure 1

Location map of the study area. Note: The designations employed and the presentation of the material on this map do not imply the expression of any opinion whatsoever on the part of Research Square concerning the legal status of any country, territory, city or area or of its authorities, or concerning the delimitation of its frontiers or boundaries. This map has been provided by the authors. 


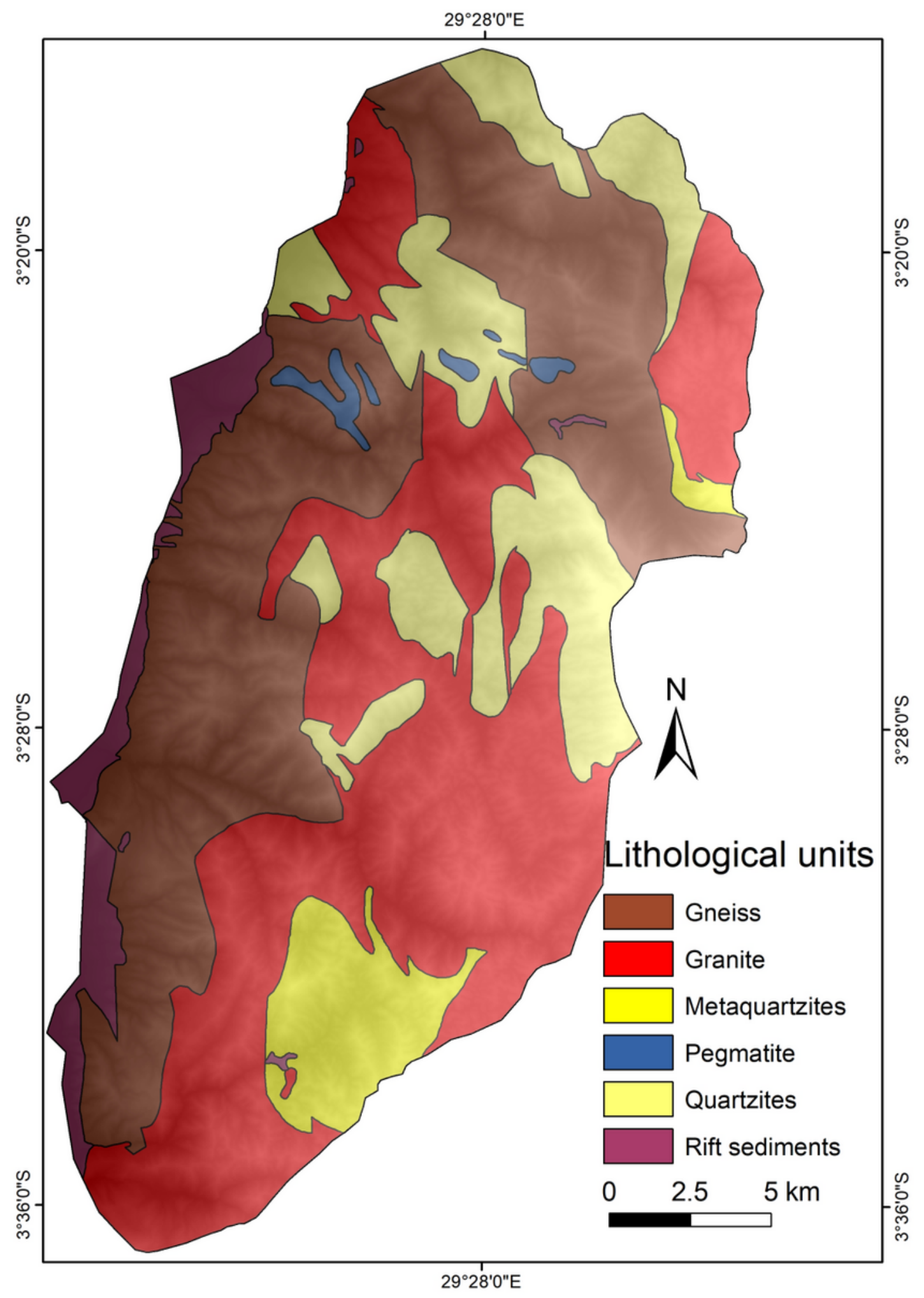

Figure 2

Lithological map of the study area (Laghmouch et al. 2018). Note: The designations employed and the presentation of the material on this map do not imply the expression of any opinion whatsoever on the part of Research Square concerning the legal status of any country, territory, city or area or of its authorities, or concerning the delimitation of its frontiers or boundaries. This map has been provided by the authors. 


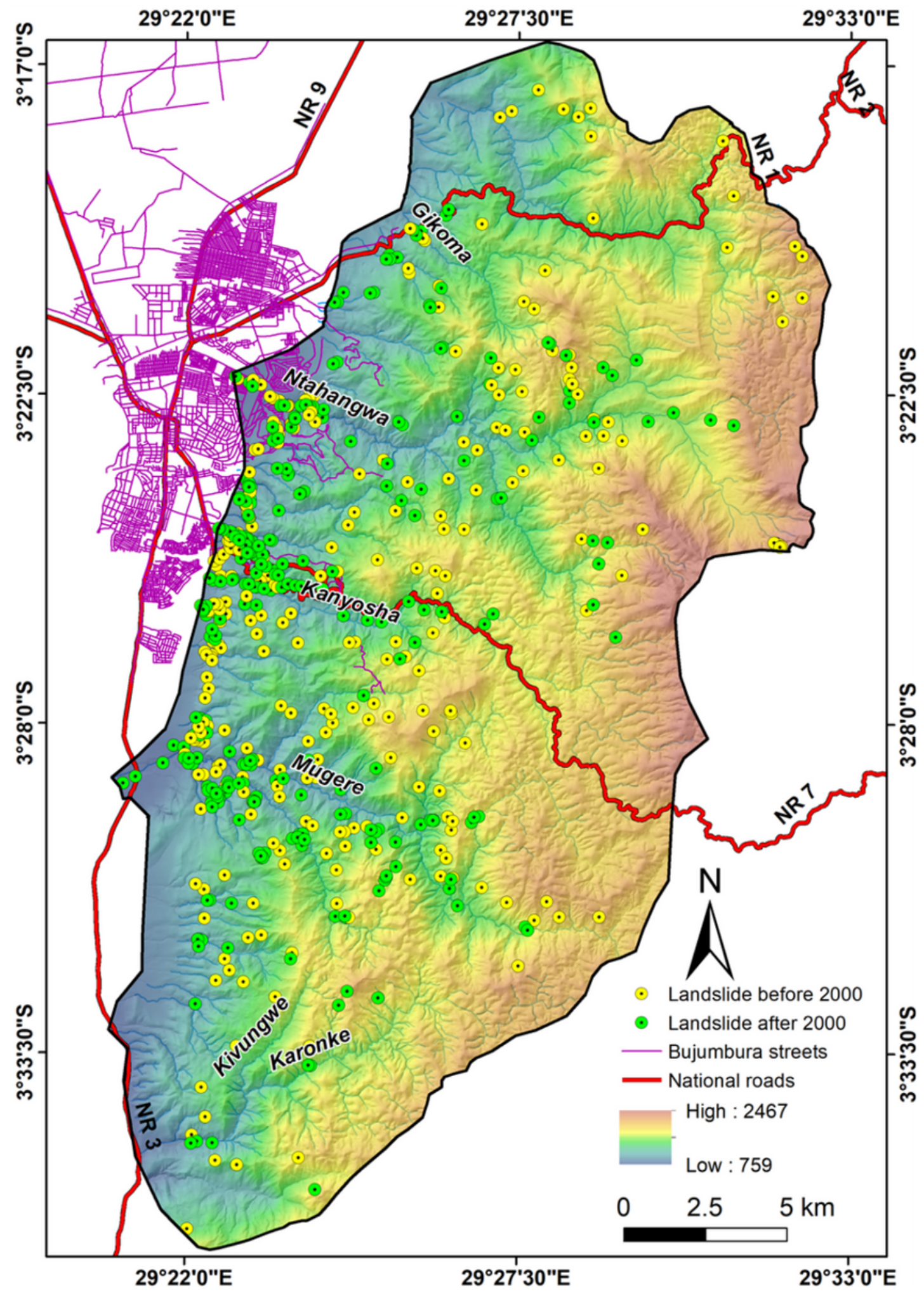

Figure 3

Location of landslides in the study area. Yellow and blue dots are landslides occurred before and post 2000 s respectively. Note: The designations employed and the presentation of the material on this map do not imply the expression of any opinion whatsoever on the part of Research Square concerning the legal status of any country, territory, city or area or of its authorities, or concerning the delimitation of its frontiers or boundaries. This map has been provided by the authors. 

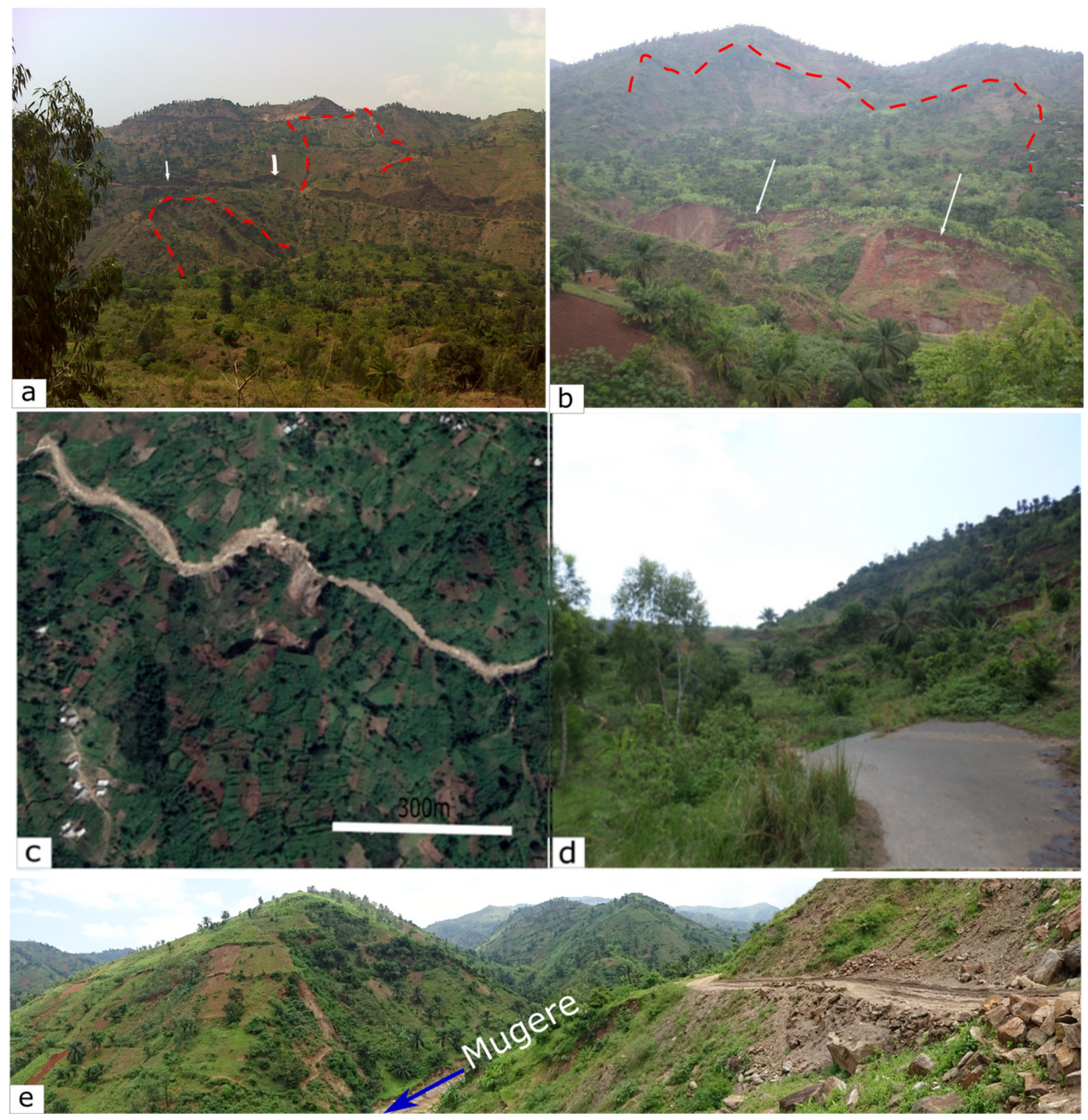

\section{Figure 4}

Typical landslides inventoried in this study. a The red lines symbolize the contours of old landslides used as control points in the susceptibility modelling and the white arrows point to small landslides related to the topographic change due to road construction, the photo was taken in August $2014\left(29,391^{\circ} ;-3,437^{\circ}\right)$. $\mathrm{b}$ In red, large active slide - earthflow with recent reactivations at the toe due to the bank erosion, the photo was taken in April $2014\left(29,388^{\circ} ;-3,433^{\circ}\right)$. c An active/recent landslide initiated in 2012, an 
example used for model validation, the image is captured from Google Earth from February 2020 $\left(29,404^{\circ} ;-3,381^{\circ}\right)$. d A road cut by a large earthflow, the photo was taken in July $2016\left(29,400^{\circ} ;-3,430^{\circ}\right)$. e View of the entire dormant deep-seated landslide (left) in Mugere catchment area and an avalanche damaged the road to Mugere hydroelectric power station (right), the first trigger occurred in 2010 and still active until now, the photo was taken in December $2018\left(29,39^{\circ} ;-3,481^{\circ}\right)$.

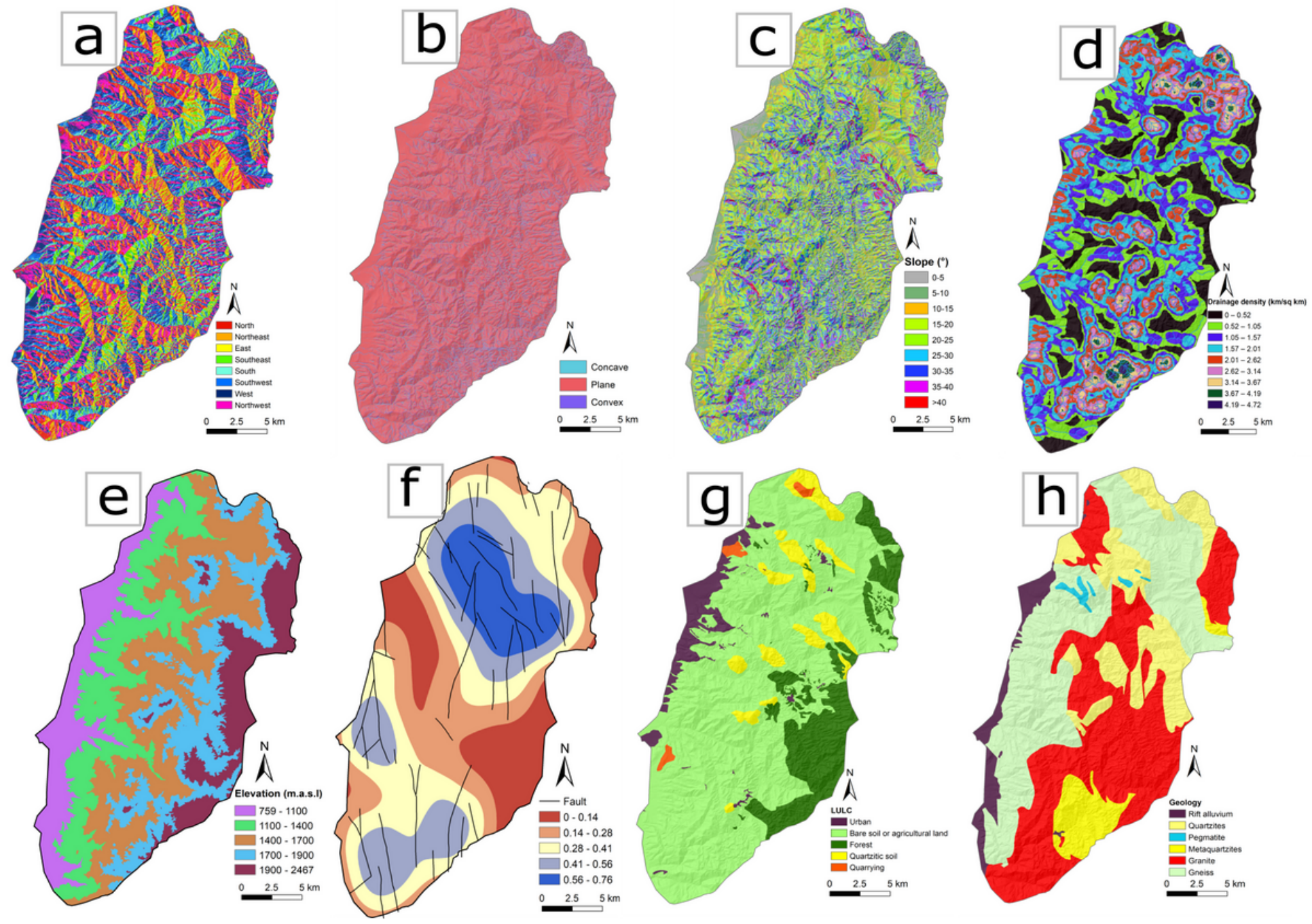

Figure 5

Input thematic layers: a slope aspect, b curvature, c slope angle $d$ drainage density, e Elevation, $f$ fault density, g lithological units, h land use. 


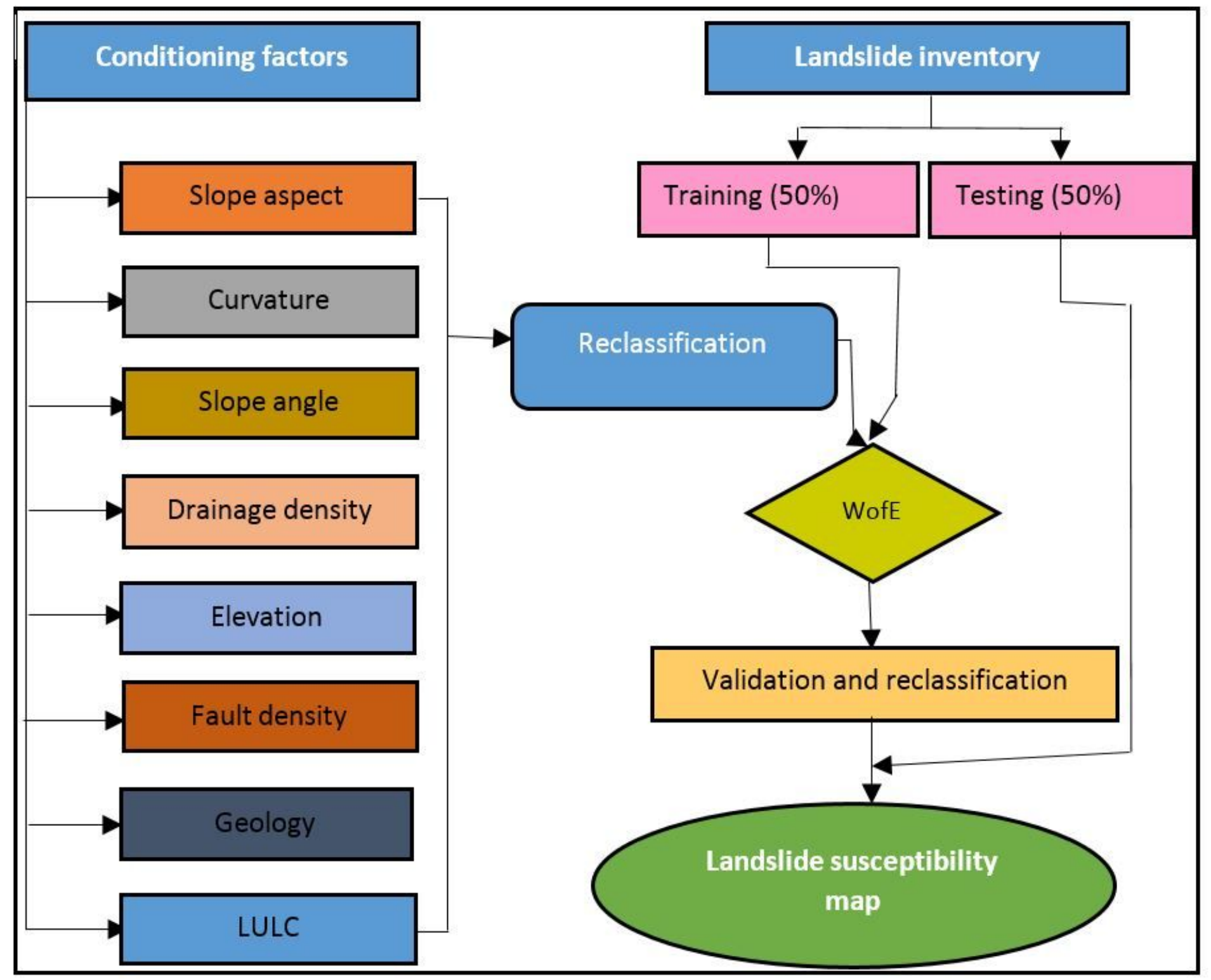

Figure 6

Flowchart of methodology used in this study. LS: landslide 

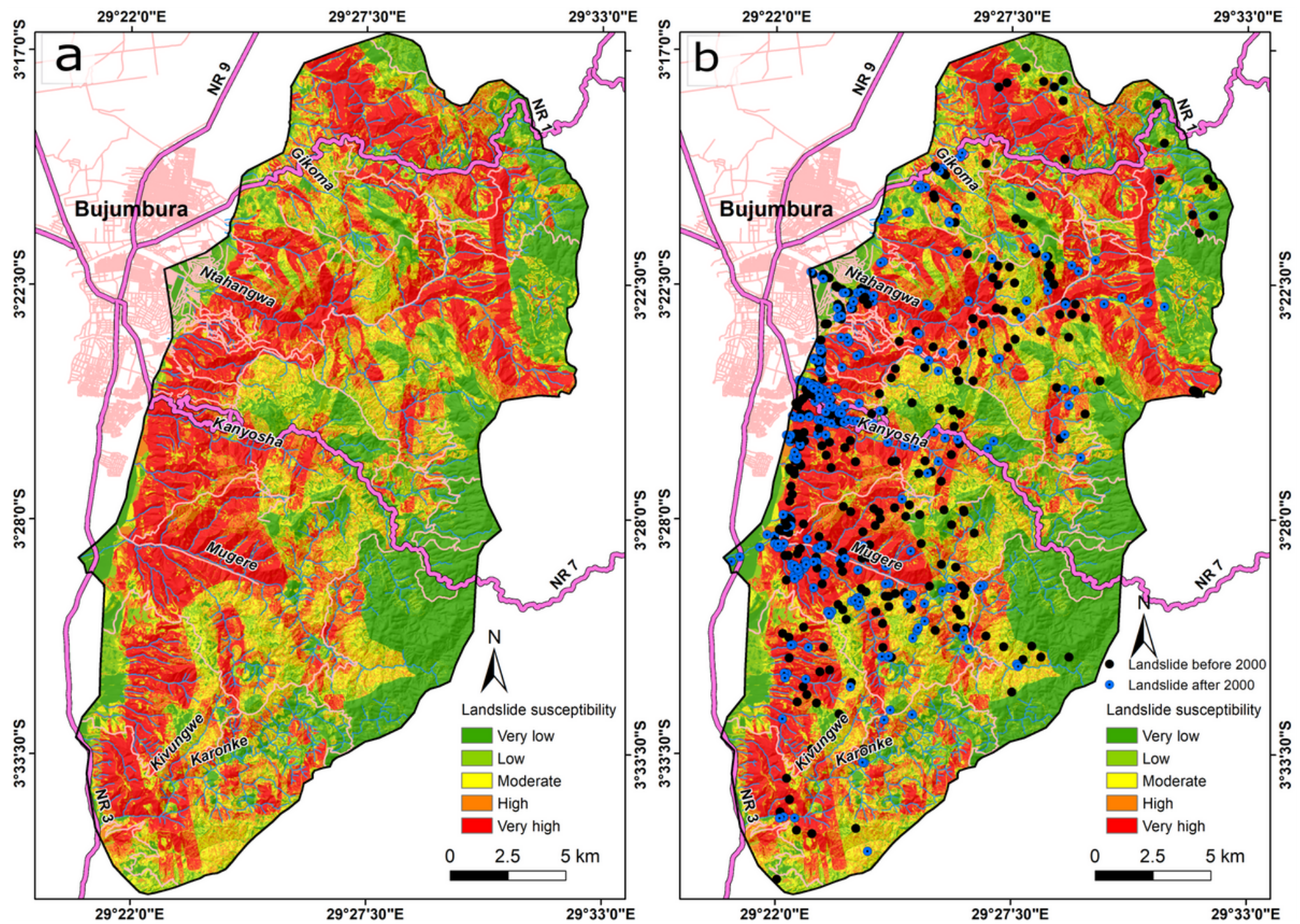

Figure 7

a Landslide susceptibility map using Weights-of-Evidence model for the study area. b Landslides plotted to landslide susceptibility map. Note: The designations employed and the presentation of the material on this map do not imply the expression of any opinion whatsoever on the part of Research Square concerning the legal status of any country, territory, city or area or of its authorities, or concerning the delimitation of its frontiers or boundaries. This map has been provided by the authors. 


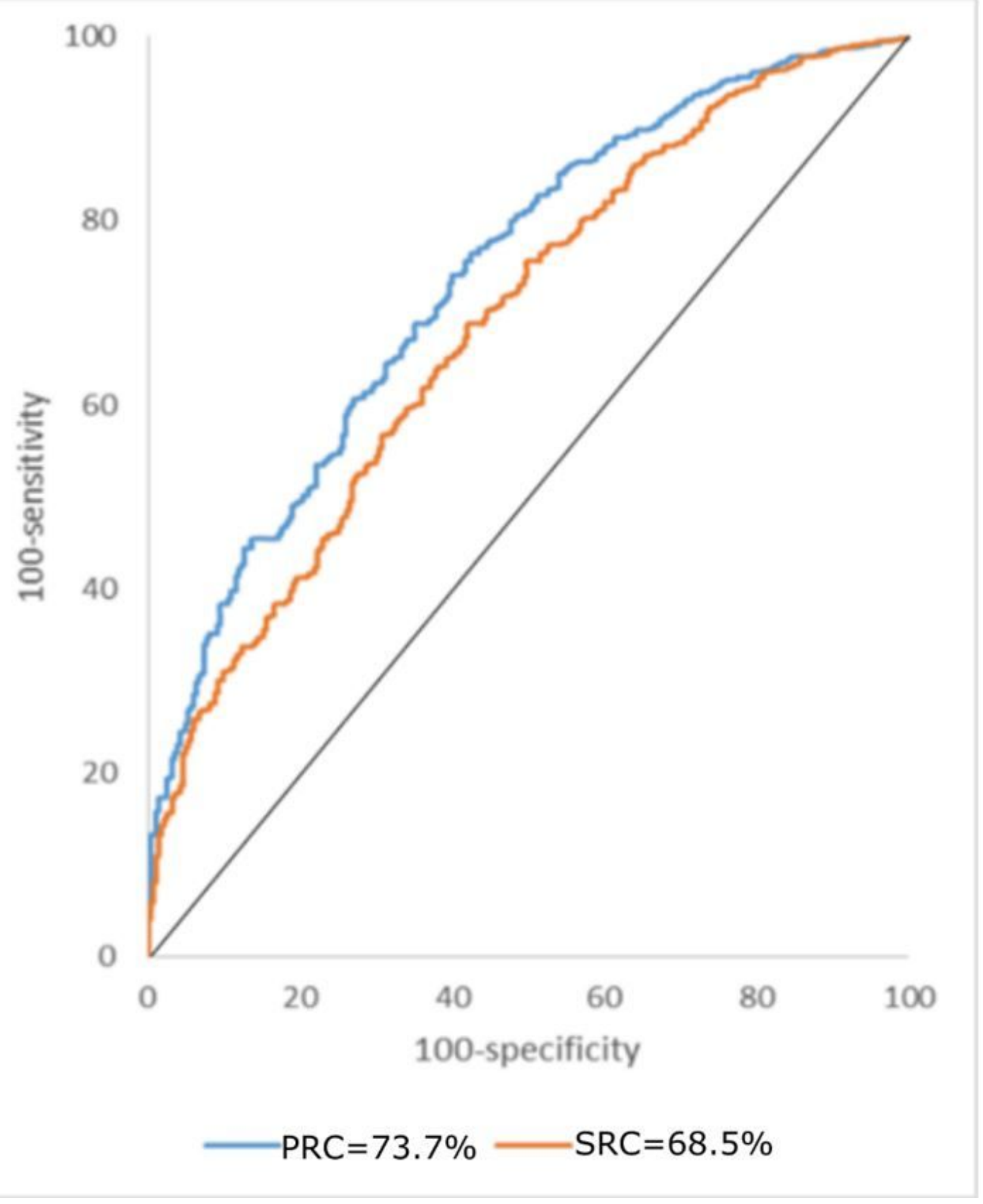

Figure 8

Success and prediction rate with AUC for WofE model performance 


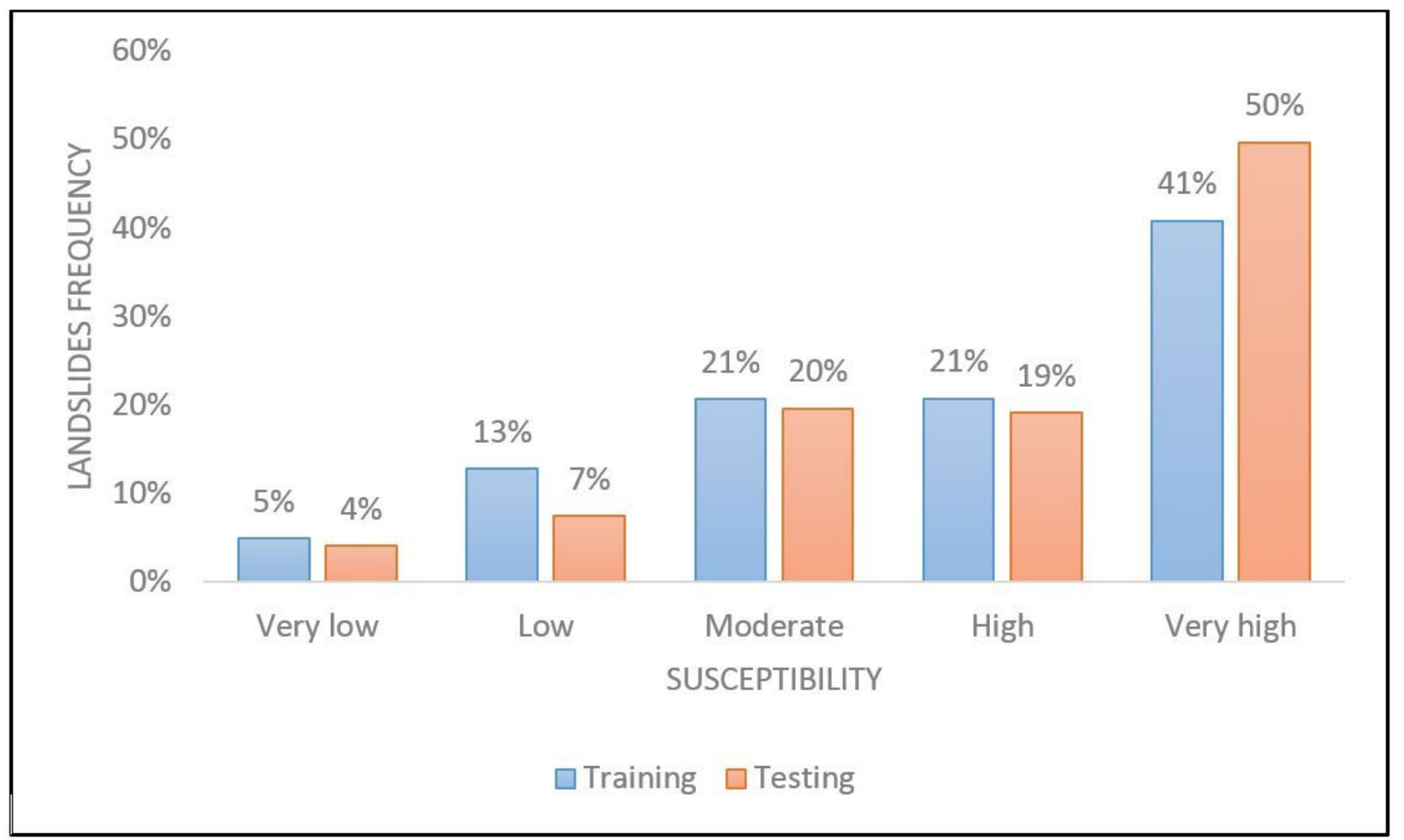

Figure 9

Percentage of landslides occurred in each landslide susceptibility class

\section{Supplementary Files}

This is a list of supplementary files associated with this preprint. Click to download.

- Table1.xlsx

- Table2.xlsx 